\title{
The Party Wall etc Act 1996: Practice pitfalls - Part 1
}

Received (in revised form): 7th October, 2005

\begin{abstract}
Alex Frame MSc, MRICS, FSAI, FFPWS, FCIOB, MCMI
is a chartered building surveyor and lectures at seminars on the subject of party walls across the country. He is a founder member of the Faculty of Party Wall Surveyors, which has an educational function to promote the proper understanding of the Party Wall etc Act 1996. He has been practising in party wall matters for 35 years. He has his own architectural and surveying practice based in west London.
\end{abstract}

\section{Abstract}

The purpose of this paper is not to give a full teaching on the subject of party walls, but to bring to attention the typical errors that are made, some of which lead to legal action. It is aimed particularly at those already practising in party wall matters in the hope that party wall surveyors will heed the advice given. It does not seem to be fully understood that party wall surveyors are preparing a legal document when making an award.

\section{Keywords:}

service, notice, building owner, adjoining owner, selected, appointed, schedule of condition, access, award, fees

\section{INTRODUCTION}

Although the Party Wall etc Act 1996 ('the Act') is now some eight years old, it has been slow to come to everyone's attention, unlike, for example the introduction of a new building regulation, particularly when those who are involved in building works need to invoke it. Of course, there are many reasons for this delay, some deliberately ignore the proper procedures, some do not know of its existence, notwithstanding that most local authorities inform the applicants at both Town Planning and Building Control approval stages, while others cannot see the point, particularly as to follow the procedures means incurring additional fees on what is usually already an expensive project.

The problem with the Act is that, while it is very powerful in its operation, it is a toothless tiger when it comes to invoking penalties for noncompliance. Basically, if the Act is ignored there are no fines, penalties or retrospective procedures, unlike with the Building Act and the Town Planning Act.

\section{COMMON ERRORS}

ADS Building Services 190 Harlington Road Hillingdon UB8 3 HA, UK Tel: +44 (o) 1895811177 Mobile: +44 (0)7050 17600 E-mail: info@party-wall.co.uk

\section{Notice}

The first lesson is to know that the Act cannot be invoked unless a notice is served. What therefore is a notice? A notice is simply conveying information about the intention to undertake certain works by the building 


\section{Not a party wall surveyor until dissent to notice}

\section{All legal documents are served}

owner to the adjoining owner that could have an effect upon the adjoining owner's property. The notice does not have to be set out in any particular way, neither does one have to use the many standard forms that are available, although they do help.

Section 3 of the Act clearly states the requirements of a notice, which are that it should give the name and address of the building owner, give the particulars of the proposed work and give the date on which the proposed work will begin. All of this information could be conveyed in a simple letter from the building owner to the adjoining owner and, because it is the duty of the building owner to serve the notice, the specific details as given in Section 2(2) $(\mathrm{a}-\mathrm{m})$ do not have to be spelled out, as is wrongly thought by many. The author has known some surveyors to reject a notice as being invalid because it did not quote the clauses applicable from Section 2.

Logic will dictate that if it falls to the building owner under the Act to serve the notice - someone who may not have any real building knowledge - how is he expected to know the technical details to convey in his notice? Of course, very often a surveyor serves a notice on behalf of the building owner, but the precise details of the Act do not need to be given, suffice to say that the notice conveys the information as to the intention of the building owner.

It is important to remember that if a surveyor serves such a notice on behalf of the building owner he is not a party wall surveyor at this point, but merely acting as a servant or agent. Why is this so, one may ask? The simple answer is that when a notice is served on the adjoining owner he may well consent to the works, if this is so, then there is no dispute, the Act is not invoked and no party wall surveyor is required. The work therefore may proceed in the same manner as before the Act came into force.

There are classic cases covering the service of a notice such as Leadbetter v Marylebone Corporation [No.1] [1904] 2 KB 893; Adams v Marylebone Borough Council [1907] 2 KB 822 and London \& Manchester Assurance Co. Ltd v O. \& H. Construction Ltd [1989] 2 EGLR 185. All of these were cases dealing with a proper notice not being served and the ensuing problems.

\section{Service}

As previously mentioned, these are legal matters and all legal papers are served. They are not issued, sent, delivered or, worst of all, published, which is commonly done by surveyors as though they have to use special jargon. Publication would be a broadcast to all, whereas service is particular upon and to the owners.

The mention of 'serve', 'served', 'serves' and 'service' occurs no less than 51 times in the Act and no other word is used. The words 'delivering', 'delivered' and 'sending' are used in the Act (Section 15), but only to describe a method by which the notice or other document is to be served. When considering the procedure in the light of formal legal court documents that are served but may be delivered by a policeman or bailiff, 
Incorrect names means an invalid document

The precise status of the party wall surveyor is important or sent in the post, only the word 'serve' should be used in written documents such as notices and awards.

\section{Owners}

It must be remembered that a notice is a legal document and as such it needs to be carefully drafted. One of the common mistakes made by surveyors is getting the rightful owner wrongly named on the notice and in the award.

When serving a notice the correct building owner(s) must be stated. For example, if the owners are Mr Brown and Mr Green then serving a notice just giving Mr Brown would deem the notice to be invalid. Even less obvious would be the case of $\mathrm{Mr}$ and Mrs Brown being the owners, if the notice was served using just Mr Brown then again the notice would be invalid. The case of Lehman v Herman [1993] 1 EGLR 172 is an example of a case where this happened and all that followed was deemed invalid.

The situation is different for adjoining owners who do not need to be named. The Act states that a notice is to be served on 'any adjoining owner'. It is therefore sufficient to serve a notice on 'the owners', or one of the co-owners such as the husband or wife, but all separate owners, such as leaseholders and freeholders of the same property, are entitled to receive a notice. Having said that, it is generally very easy to establish the correct name(s) of the owner(s) by logging on to the Land Registry website and, for a fee of $£ 2$, the name(s) can be rightfully established. Of course, not all properties are registered but most are and, in the next few years, all are likely to be.

\section{Selected or appointed}

Apart from one particular matter under this heading the Act is very clear. When a notice has been served and dissent is made either by notification or lack of response, thereby bringing a deemed dissent, the duty of the building owner and adjoining owner is to appoint a surveyor in order to resolve the dispute that has arisen between them. Both owners can concur in the appointment of one surveyor who will become the agreed surveyor. One of the areas of error is that when the adjoining owner fails to appoint a surveyor the matter is left open for the building owner to make an appointment, and he must do so, but he is not at liberty to appoint his own surveyor as the agreed surveyor. The building owner under these circumstances must appoint a separate surveyor. An agreed surveyor can only be appointed by the two owners, which is why he is so-called, because he is the surveyor to be used that has been agreed between the parties.

The first action above all others to be taken by the two surveyors is to select a third surveyor. This is where one should take note that the duty is to select and not to appoint, because clearly there is a difference. A common mistake in awards is the clause referring to the selection of the third surveyor, which then goes on to say that in the event that the selected surveyor is unwilling or unable to act, another surveyor shall be appointed by the President of the Royal 
Institution of Chartered Surveyors'. In fact, there are two mistakes here, first, another surveyor must be selected not appointed and, secondly, the selection is to be made in accordance with the Act, which is to say the local authority, not the President of the RICS or anybody else for that matter because such people are not mentioned in the Act.

The confusing area is the particular matter first mentioned. The Act says in Section 10(8) that the selection is to be made by 'the appointing officer', who under Section 20 is 'the person appointed under this Act by the local authority to make such appointments'; however, he is the person who selects the third surveyor under Section 10(8)(b). The third surveyor only becomes appointed when he is requested by either party or either surveyor to determine a particular matter. His position then changes from being selected to appointed when therefore he becomes eligible for fees.

\section{Access}

This is an area that generally carries two problems of misunderstanding. It has been a common belief that an Englishman's home is his castle, a threshold that legally cannot be crossed uninvited, save 'powers' to enter with a warrant, for example. The Access to Neighbouring Land Act 1992, however, brought about a change whereby access to a neighbour's land could be obtained legally if it was for the purposes of maintenance and repair to one's property but, it must be stressed, not for new building purposes only. The Access to Neighbouring Land Act 1992 therefore has weakened the stronghold. Then there is the Party Wall etc Act 1996, under which in certain circumstances access to a neighbour's 'castle' is permitted for building works.

The matter of access is dealt with under Section 8 of the Act, in particular clause 1 . This section says who can enter, when they can enter, how they can enter and for what reason they may enter. Some surveyors have 'threatened' their right of access upon adjoining owners because they need to get into the premises in order to prepare a schedule of condition. They have been known to be ready with a policeman and a locksmith to break an entry saying they have the right to do so as given by the Act. This is not necessarily correct, however, as the Act does not give this right for this purpose.

If one looks more closely at the wording, Section 8(1) says that access is obtainable 'for the purpose of executing any work in pursuance of this Act'. One can then say that a schedule of condition is not in pursuance

What is the purpose for access of the Act, in fact the schedule of condition is never mentioned in the Act and an award can be made without it; indeed awards have been made and served without any such schedule being prepared. It is always prudent, however, to prepare a schedule of condition for this is in the interests of both building owner and adjoining owner and one should be taken wherever possible.

Consider that if an adjoining owner denies access for the purpose of preparing a schedule of condition, then he is working against himself, but in most cases access is granted. If the adjoining owner's heels are 
dug in, however, then for what logical reason would a surveyor want to force an entry upon him? The surveyor should simply say 'so be it' and warn that if damage occurs the adjoining owner may find it difficult to prove.

It is very likely that a judge would uphold the adjoining owner's rights, because a schedule of condition is not a requirement to resolve a dispute under Section 10 of the Act, which is the reason for surveyors being appointed in the first place. Nevertheless this may need to be tested at law for the author knows of no case concerning access for this sole purpose.

To clarify Section 8(5) of the Act whereby a surveyor 'may ... enter and remain on any land or premises for the purpose of carrying out the object for which he is appointed'. The answer may be in the latter part of the statement: 'the object for which he is appointed'. The surveyor is appointed under Section 10 to resolve the dispute between the owners. A judge would consider that he could undertake his duty of resolving the dispute perfectly well without the necessity of preparing a schedule of condition. It seems reasonable that access could well be denied for such a purpose, claiming a right under Section 8 , but of course, others might view this differently.

As a point of interest one should note Section 8(2) that if the premises are closed then breaking an entry may be permissible. 'Break open any fences or doors in order to enter the premises' is what the Act states, so no one should try breaking in through a window because, while this would comply with the spirit of the Act, it would not comply with the letter of the Act.

A similar mistake would be to demand access to ascertain the depth of the adjoining owner's foundation in order to know whether a notice should be served or not. This is certainly not covered by the Act, possibly for no other reason than the Act is not invoked until a notice $i s$ served. Where there is doubt about the depth of the foundation of neighbouring property the legal advice of some is to serve a notice 'without prejudice', although it is unclear whether this would have any real legal standing.

A common error relates to a notice served under Section 6. Under Section 1 when the proposed work is to build on the line of junction, the Act gives the right to access the neighbour's land in order to build, which would include the right to scaffold etc. Similarly, under Section 2 access is clearly available in order to carry out the work on the party wall. The key to the matter relating to access under a Section 6 notice is the purpose of the works, which must be for excavation in order to build. After the excavation is completed the matter is closed and, in simplistic terms, the award is complete. Access to build is not covered by this notice and consequently such rights for scaffold generally would be denied because one does not need scaffolding to excavate.

\section{Retrospective awards}

A very common action is when a building owner starts the work without serving a notice. What can be done? The short answer under the Act is 


\section{The Act makes no provision for work already done}

absolutely nothing. What frequently happens is that a surveyor acting on behalf of his client and not on behalf of the Act gets himself involved when in fact the only real advice that can be given is to serve an injunction to stop the works.

Needless to say, getting an injunction is not as easy as one might expect because one has to give good reasons to a judge to convince him to serve an injunction. This is rightly so, for if it were easy, all sorts of flippant reasons could thwart the building works. The questions to consider are as follows.

- What is the reason for an injunction? It will not be given simply because a notice has not been served.

- What will be the legal costs involved as it could well be that they will not be all claimed back?

- What damage has been caused or is likely to be caused?

- What loss will be incurred?

- How will you be affected if there were no injunction?

Unless one can show good cause for an injunction to be served it will not be done. If the adjoining owner pursues the matter to court, however, the judge would be quite likely to give directions as to remedy in directing the building owner to serve notice and for the surveyors to do their duty in accordance with the Act.

Surveyors are aware of the above but need to guide the adjoining owner properly on the matter, it is sad to say that many surveyors are fee driven and will attempt to invoke the Act. Of course, they may be successful in convincing the building owner to serve a notice, but if the work has been done already the notice would be invalid.

If, as previously mentioned, the work has been completed, anything retrospective is meaningless and any award served would clearly be invalid. At best, surveyors could check the works and agree remedies if damage has occurred, but this would be outside of the Act and merely dealt with at the common law level.

The logic is clear in that the reason for serving a notice is to inform the adjoining owner of intended works covered by the Act that are to be carried out. It therefore follows that if the work has been done then any form of notification is useless. Despite this, some surveyors contrive to serve a retrospective notice followed by a retrospective award for which the Act makes no provision.

\section{Fees}

Age-old questions and problems arise around the matter of fees. Sometimes it seems that this is the only thing on the surveyor's mind. While everyone wants to get paid for what they do, this is not the purpose of the Act and surveyors should remember that they are appointed to administer and implement the Act in order to resolve a dispute between the owners.

It is illegal to hold an award in lien against fees. Once the award has been agreed and signed by the appointed surveyor(s) it must be served 
forthwith as stated in Section 10(14) of the Act. There is no reason for a surveyor not to be paid immediately after he has served the award, but he should not be paid before. Many awards erroneously state that immediately upon signing of the award the building owner shall pay £xxx'. Unless the building owner is there at the time of signing, and it is highly unlikely that he would be, he cannot comply with this statement. The wording should say 'immediately upon serving'.

The Act actually covers the matter of fees under Section 17, a short section that simply states: 'any sum payable in pursuance of this Act (otherwise than by way of fine) shall be recoverable summarily as a civil debt'. In other words, one can sue in the county court, as with any other matter where fees are not paid, or in the lesser-used facility, the magistrates court.

It is beyond this paper to determine what fees should be charged and there is no fee scale, nor should there be for that matter. The Act says under Section 10(13) that reasonable costs incurred in making the award shall be paid.

While the building owner can ask at the outset before making an appointment as to the likelihood of the fee he will incur, thus allowing him the option to appoint that surveyor or not, he is not able to do this with the adjoining owner's surveyor for he has no control over his appointment. Some would suggest that this is unfair as the building owner, in the vast majority of cases, is the one who has to pay all the fees. It clearly has to be this way, however, otherwise the building owner could thwart the choice of the adjoining owner's appointment of a surveyor until he is satisfied with the fee he will have to pay.

It has to be remembered that the building owner is the one wishing to undertake the works, and the adjoining owner is quite happy with the status quo. If dissent to the notice is made then the adjoining owner has rights under the Act, in which one of his rights is to appoint a surveyor of his choice and not the building owner. It would be rather like questioning a choice of solicitor when attempting to resolve a dispute between parties.

Problems very often occur because the level of fee claimed by the adjoining owner's surveyor is considered too high. The key

The fee should be reasonable word in the Act concerning fees is 'reasonable'. A word used much in law, but what is a reasonable fee? The short answer is common sense and the proverbial 'Clapham Omnibus'. That is to say, how long will it really take to undertake this work in man hours that can be justified?

For example, assume that the two surveyors meet on site for one hour, usually to prepare a schedule of condition. Then assume that a draft award is sent to the surveyor for comment. How long will it honestly take (an experienced surveyor) to read a few pages and comment - one hour - bearing in mind that the award usually contains many standard acceptable clauses. Now assume that the surveyor allows for one further site inspection during the works and one for the completion to check off the schedule of condition, although most surveyors do not undertake 
Make sure the award will stand a challenge the latter, but that is another matter, it is usually allowed for - one further hour or so at most. Then add the paperwork and telephone calls etc another hour in all. In truth, the total then is only about four-five hours. Too simplistic some may say, and they will add another two-three hours and call it a day's work at eight hours. Multiply this by the hourly rate and there is the 'reasonable' fee.

Like all good project management it is wise to keep a good paper trail, and to this end keep a careful note of time and expenses relating to each individual project. If one is asked to justify a fee there will be the account to show.

Clearly this only outlines a simple case, but the principle is there to see, so any suspicion of a high fee should be questioned and refused if needs be. One method is to suggest that there is a typing error and ask the issuer to re-check, which also quite often brings a reduced fee. Unfortunately, there are some unscrupulous surveyors about who know just where to pitch the level of fee, knowing that a trip to the third surveyor will attract his fee which may result in 'swings and roundabouts', but here is not the place to dwell on that.

When surveyors who are appointed well outside of the geographical area of the work, however, and the entitlement is for the owners to do so, it would be unreasonable to expect the building owner to pay additional travelling costs for such a surveyor. It is also unreasonable to pay 'London' rates for provincial works, particularly if the works are of a minor nature. This is notwithstanding that some party wall matters can be quite complex and warrant an experienced surveyor who may well come from out of the area.

\section{Challenging an award}

As previously stated, an award is a legal document and therefore it has to be prepared with care because if it is not it will, or at least can be, challenged in court. In Section 10(16) of the Act it states: 'the award shall be conclusive and shall not except as provided by this section be questioned in any court'. This quote relates just how powerful this legal document is, however, if it is challenged then generally something clearly has gone wrong. It would be impossible to give all the reasons for making a legal challenge, but this paper now will touch on some of the common errors made.

An award may be deemed ultra vires, which simply means 'beyond one's powers' if it tries to deal with matters outside of the Act. An award also can be challenged if it is wrong 'on the face of it', for example, the recitals give the owners' and surveyors' names incorrectly etc.

It must be remembered that the surveyor(s) draws up an award as an agreement between two owners because a dispute has arisen. It is therefore only possible for the award to be challenged by the owners and never the surveyors as some might think. The challenge is made in the county court by the claimant (one owner) and defended by the respondent (other owner) in appealing the award. This is a right given to them under Section 10(17) of the Act. The legal costs are a matter for the owners and not the surveyors. It could well be that a separate 
action is taken against the surveyor(s) if total negligence is seen to be the case. So while the party wall surveyor has great powers under the Act and is protected by it, common sense will tell that the matter is still open to the law.

The obvious advice is to be careful how the award is drawn up and ensure that the contents are correct and legally valid, otherwise surveyors will be costing the owners money and clearly they will seek redress. One of the common faults that surveyors make is in the writing of the following clause: 'that fourteen days after delivery of the award the building owner shall be at liberty to...'. First, the award is served not delivered as explained previously, but more importantly the mistake in prohibiting the works from commencing until 14 days has passed is illegal under the Act.

The Act is quite clear, from the moment the award is served the building owner may proceed; surveyors cannot make him wait any given period of time. This has come about through misreading Section 10(17) where it says that either parties to the dispute may appeal against the award within 14 days and surveyors link this with Section 10(14) where by their duty is to serve the award forthwith once it has been prepared. The belief is that if 14 days are given to appeal then the award can be challenged and the works cannot start.

The fact is true that an award can be appealed, but it is also true that this is very rare given the numbers that are prepared by surveyors every day across the country. The correct procedure would be either to include a clause outlining the 14-day challenge open to the owners or, more usually, simply to put in a separate letter when serving the award on the owners.

The reason behind not imposing the 14 days, or any other period for that matter, is that it would be unjust to make the building owner wait. He may have a signed agreement with the contractor, and the contractor may be tied to a tight building programme whereby a delay in starting could prove seriously expensive, particularly on a large project.

\section{EXPERIENCE}

All experience is good, as hopefully lessons are learnt from the mistakes

\section{Ensure you continue to learn}

of what people call bad experience. Without mistakes one does not learn, as one is commonly told. Some indignant surveyors claim that 'I have been doing it this way for 25 years' to which one can only reply that they could have been doing it wrong for 25 years. The author has to confess here that he was one such surveyor who like others was relying upon his predecessors with more experience to be correct in all that they did and wrote. Then one day he read the Act for himself and to his disgrace discovered he had been making many mistakes for many years and somehow had got away with it!

If surveyors enjoy party wall work then they will want to get it right as much as they can, bearing in mind there always will be some differences of opinion for certain 'grey' areas, and this must be respected. It is recommended that surveyors do their own homework, building up their own knowledge and experience. The closing words therefore are: 
'Let the Act be your guide, add nothing and take nothing away from the contents and you will not go wrong'. An obvious statement to make perhaps, but if surveyors heed it well they will not end up in court, at least not on the wrong side.

\section{Note}

The use of the words 'he' or 'his' is not gender-specific. 